\title{
Exploring the Impact of Positing Entrepreneurship in Nature of Science: Initial Science Teachers' Perspectives
}

\author{
Sila Kaya-Capocci ${ }^{1}$, Orla McCormack ${ }^{2}$, Sibel Erduran ${ }^{3,4}$, Naomi Birdthistle ${ }^{5}$ \\ ${ }^{1}$ Faculty of Education, Agri Ibrahim Cecen University, Turkey \\ ${ }^{2}$ School of Education, University of Limerick, Limerick, Ireland \\ ${ }^{3}$ Department of Education, University of Oxford, Oxford, UK \\ ${ }^{4}$ Norwegian Centre for Science Education, University of Oslo, Norway \\ ${ }^{5}$ Department of Business Strategy and Innovation, Griffith University, Queensland, Australia
}

\begin{abstract}
Purpose: The social aspects of Nature of Science (NOS) have become more eminent, but entrepreneurial perspectives of NOS continue to be neglected. Entrepreneurship is relevant to NOS and science education due to its role in scientific enterprises and its importance as a $21^{\text {st }}$ century skill required in all subjects, particularly STEM subjects. Due to the impact of Initial Teacher Education (ITE) and the science curriculum on Initial Science Teachers' (ISTs) understanding, this paper explores the impact of including entrepreneurship in NOS with ISTs.

Design: This qualitative study investigated the changes in three ISTs by examining their understanding of entrepreneurship within NOS, and their perspectives on the inclusion of entrepreneurship in the science curriculum following an intervention. The results were analysed through thematic and network analysis (NA).

Findings: The results indicated that following an intervention, ISTs developed a more holistic understanding of entrepreneurship in NOS and could see the benefits and rationale for including entrepreneurship in the science curriculum. Certain concerns remained, however.

Originality: Although entrepreneurship may contribute to NOS by promoting scientific development, enhancing interest in science, and developing a holistic understanding of science, a thorough review of the relevant research literature suggests that studies investigating entrepreneurship in NOS are rare. This paper fills this gap by exploring Irish ISTs' perspectives on positing entrepreneurship in NOS. The study suggests conducting further research on the integration of entrepreneurship in the science curriculum and its impact on ITE.
\end{abstract}

\section{Introduction}

The prominence and importance of Nature of Science (NOS) have been highlighted, particularly over the past two decades (Clough, 2011; Kampourakis, 2016). NOS aims to understand how science and scientists work by incorporating a range of cognitive, epistemic, social, political, historical, and economic perspectives into science education (Erduran and Dagher, 2014; Irzik and Nola, 2014; Matthews, 2012). The social aspects of science have also 
recently become more eminent (Park et al., 2020). Despite this, entrepreneurial perspectives of NOS continue to be neglected, with some advocating for its inclusion in NOS (Kaya et al., 2018).

A literature review conducted by Deveci and Seikkula-Leino (2018) on entrepreneurship in teacher education from 2000 to 2016 found a body of research highlighting the importance of entrepreneurship in teacher development and recommended the inclusion of entrepreneurship into Initial Teacher Education (ITE), including Initial Science Teacher Education (ISTE). Entrepreneurship is relevant to NOS and science education due to (a) its role in the scientific enterprises to develop technology, science, society, economy and environment (Busch and Lacy, 2019; Irzik and Nola, 2014) and (b) being a competence included in the $21^{\text {st }}$-century skills that are required in all subjects, particularly STEM subjects (Anderson et al., 2017; Department of Education and Skills (DES), 2016; Wilson et al., 2009). A thorough review of the relevant research literature conducted in this study suggests that studies investigating entrepreneurship in NOS are very rare.

Teachers are the most important agents affecting the development of educational policy and the implementation of change inside their classrooms (Li and Ruppar, 2021). Teachers are more malleable during their ITE programmes and are less open to new perspectives once qualified (Decker and Rimm-Kaufman, 2008). In this sense, ITE is one vehicle through which IST's understanding can be changed. ISTE should pay more attention to the applications of entrepreneurship in NOS and science education because entrepreneurship is involved as one of the aspects of the curriculum (European Commission, 2012). Therefore, drawing on a novel approach to data analysis, network analysis (NA), this paper explores the impact of including Entrepreneurship in NOS with science teachers engaging in their ITE. To do so, the place of entrepreneurship in NOS is, firstly, presented. Secondly, what the research says about embedding entrepreneurship into curriculum and ITE is elucidated. Thirdly, the methodology, including a detailed description of NA, is introduced and finally, the results are outlined and discussed.

\section{Entrepreneurship in Nature of Science}

NOS has been studied for decades (Allchin, 2011; Irzik and Nola, 2011; Kampourakis, 2016; McComas et al., 1998; Park et al., 2020). Recently, Kaya et al. (2018) argued for the inclusion of the economics of science and entrepreneurship into NOS. Entrepreneurship in NOS can be defined as:

the process of establishing new economic, social, institutional, cultural and scientific environments or organisations to create future products and services by realising the opportunities and their possible failures and using required resources (Kaya, 2019, p.67)

Even though at first glance, entrepreneurship might be perceived as utterly different from the NOS perspective, they are interwoven. Many researchers found the characterisation of science 
related to the economic features of science and the maintenance of the scientific enterprise (Allchin, 2011; Erduran and Dagher, 2014; Irzik and Nola, 2014). A scientific enterprise may be seen as a crossbreeding of science and entrepreneurship, and commonly refers to a project that has a scientific basis and is developed by or in collaboration with an entrepreneur. Scientific enterprises collaborate with entrepreneurs and learn from entrepreneurship to help develop technology, science, society, economy, and environment (Etzkowitz, 2008; Sanders, 2007). Therefore, it may be said that entrepreneurship is one of the key co-operators of a scientific enterprise. Developing an understanding of the scientific enterprise is important to help citizens to make systematic, rational decisions about projects involving scientific endeavours and technology (Peters-Burton and Baynard, 2013). Other studies were also published about scientific enterprises in different fields. For example, Busch and Lacy (2019) explored agricultural scientific enterprise. Irzik and Nola (2014, p.1003) argued the enterprising feature of science by stating that:

"...science is many things all at once: it is an investigative activity, a vocation, a culture and an enterprise with an economic dimension and accordingly has many features (cognitive, social, cultural, political, ethical and commercial)"

Entrepreneurship is also viewed as a skill. In the 1980s, Timmons (1989, p.1) defined entrepreneurship as "the ability to create and build something from practically nothing, it is initiating, doing, achieving and building an enterprise or organization rather than just watching, analysing or describing one". As part of entrepreneurship, Hisrich and Peters (2002) referred to higher-order skills, such as critical thinking, decision-making, risk-taking, problem-solving, creativity and innovation skills, which are important in NOS. Wilson et al. (2009) addressed three types of skills:

1. science, technology, engineering and math (STEM) skills,

2. learning skills, such as critical thinking and problem-solving,

3. life skills, such as leadership and citizenship.

The European Commission (2012) reported additional skills, such as communication, representation, planning, teamwork and exploring opportunities. Such entrepreneurship skills are also included in $21^{\text {st }}$-century skills that are required for today's young people to realise their full potential, prepare them for the challenges of higher education and/or career development (DES, 2016; Wilson et al., 2009). McCallum et al. (2018) proposed the EntreComp framework to help understand what is meant by entrepreneurship as a key competence for lifelong learning and support building the entrepreneurial capacity of European citizens and organisations. This framework can be utilised if such skills were to be integrated into the science curriculum.

Different state politics, such as the welfare state and the neo-liberal state, affected academia, market and industry and resulted in the emergence of a triple helix, i.e. the university-industrygovernment relationship (Etzkowitz, 2008). Entrepreneurial universities were formed as a result of these relationships with the aim of contributing to the social and economic development of countries by providing employment, career opportunities and developing $21^{\text {st }}$ - 
century skills (Kaya, 2019). Entrepreneurial universities first emerged in the USA (e.g. Massachusetts Institute of Technology - MIT) and then adopted by other neoliberal or welfare states (e.g. Finland), which might make entrepreneurship a stronger part of ITE than the other countries. As observed in Enterprise 2025 Renewed (Department of Business, Enterprise and Innovation, 2018), the government's overall jobs strategy in Ireland, converging relationships between universities and industry is challenging educational institutions to prepare industryready graduates equipped with the required skills for employability (Hynes, Costin, and Birdthistle, 2010). Such an example also indicates that the curriculum is contextually shaped and influenced by the social, political, economic and cultural context within which it is situated (Cornbleth, 1990). International trends of neoliberalism, globalisation and marketisation result in many jurisdictions placing a greater emphasis on entrepreneurship in curricula (Leask, 2008). Inclusion of entrepreneurship in the curricula can contribute to creating industry-ready graduates, who are equipped with the required skills, by providing personal and career support (Bakhshi et al., 2017), helping them to come up with new business ideas (McCallum et al., 2018), providing self-employment as a career opportunity (Achor and Wilfred-Bonse, 2013; Bruyat and Julien, 2001), and creating entrepreneurial scientists (Buang et al., 2009). Creating such graduates might eventually help overcome the shortage of STEM workers emerging at all levels (McLoughlin et al., 2020). Additionally, STEM graduates equipped with entrepreneurship skills could make discoveries and inventions and transfer them to the market for public use, which in turn advances society. This would in turn contribute to the social and economic development of a country (Amos and Onifade, 2013; Etzkowitz, 2008; Saravatsky and Venkataraman, 2011).

Integration of entrepreneurship and NOS may also help with developing a holistic understanding by explaining how science works in society (Kaya et al., 2018; Matthews, 2012). Integration of the social-institutional aspects of science in science education has been investigated in previous studies, for example in the context of integrating economics of science in science education (Erduran \& Mugaloglu, 2013), students' understanding of the socialinstitutional aspects of science (Akbayrak \& Kaya, 2020) and pre-service teachers' learning to teach NOS (Kaya et al., 2019). This mission would not be complete unless entrepreneurship is used to illustrate how scientific knowledge, products and services are transferred from academia and industry to the market. Without entrepreneurship, it may be difficult to convey the outcomes of science to the public, which ends up in science not actualising itself. Furthermore, developing students' skills, increasing the authenticity of science and enhancing cross-curricular links through entrepreneurship, may result in students realising science as part of everyday life and thus comprehending science in its entirety (Clough, 2011; Erduran and Dagher, 2014; Irzik and Nola, 2011, 2014).

Overall, entrepreneurship is relevant to NOS due to (1) its role in scientific enterprises to develop technology, science, society, economy and environment and (2) its competences included in the $21^{\text {st }}$-century skills that are required in all subjects, particularly STEM subjects. Entrepreneurship may contribute to developing a holistic understanding of science, which may promote scientific development and interest. However, a thorough review of the relevant 
research literature suggests that studies investigating entrepreneurship in NOS are very rare. After arguing the relevance of and reasons for positing entrepreneurship in NOS, the next section demonstrates the literature conducted on entrepreneurship in Initial Science Teacher Education (ISTE).

\section{Research on Entrepreneurship in Science Teacher Education}

Although numerous studies are conducted on entrepreneurship, the literature points to the negligence of entrepreneurship in ISTE. Deveci and Seikkula-Leino (2018) reviewed the literature on entrepreneurship in teacher education from 2000 to 2016 and found 76 relevant studies. The review yielded a body of research that highlighted the importance of entrepreneurship in teacher development and recommended the inclusion of entrepreneurship into ITE. The review showed that the studies mostly explored students' and educators' perceptions of and attitudes towards entrepreneurship education. Other commonly researched aspects included methods, techniques, models or strategies used in entrepreneurship education. For example, the European Commission (2012) provided national strategies and potential competences for the implementation of entrepreneurship education in the European curricula. Seikkula-Leino et al. (2010) and Gustafsson-Pesonen and Remes (2012) discussed the role of teachers in, as well as the implementation of, entrepreneurship education. The perception of initial teachers on entrepreneurship/entrepreneurial learning was explored by Lepisto and Ronkko (2013) in Finland and Ehrlin et al. (2016) in Sweden. Studies of entrepreneurship were also conducted in different STEM subjects, such as science (Anderson, Hinz, and Matus, 2017; Jiang, Xiong, and Cao, 2017), technology (Ezeudu et al., 2013), engineering (Jiang et al., 2017; Wang and Kleppe, 2001), and mathematics (Palmer and Johansson, 2018).

Overall, the research shows that the inclusion of entrepreneurship in ITE is required to support the engagement with the curriculum and increase the effectiveness of the teaching process (Amos and Onifade, 2013; Anderson et al., 2017; Lepisto and Ronkko, 2013). Therefore, integrating entrepreneurship into ISTE may be beneficial (Achor and Wilfred-Bonse, 2013). Due to this inference, we reviewed the literature on entrepreneurship in ISTE between 2015 and 2021. Even though there is a considerable amount of research on entrepreneurship in education/teacher education, a limited number of studies focused specifically on ISTE. The literature review showed 11 studies (Appendix 1) on entrepreneurship in ISTE. Most of the studies were conducted in Turkey $(n=6)$, which is followed by Nigeria $(n=4)$. The overall tendency of the methodology selection was towards quantitative research methods, particularly surveys $(n=5)$. The studies were mainly focusing on the ISTs' perception $(n=4)$, entrepreneurial competence, including mindset and characteristics $(n=5)$ and conceptualisation $(n=3)$. Even though the studies support the inclusion of entrepreneurship in the curriculum and ISTE, its benefits and the ways to implement it were not explored within the reviewed articles. This is something the current paper aims to address. The following section briefly presents the place of entrepreneurship and NOS in the science curriculum with a specific focus on Ireland. 


\section{The Research Context}

Nature of Science (NOS) has been included in the science curriculum of many countries such as Ireland, the USA and Turkey. The literature showed that the majority of the entrepreneurship studies in ISTE are conducted in Turkey implying that the research interest may be driven by the inclusion of entrepreneurship in the science curriculum. Due to Ireland being the research context of this paper, the science curriculum of Ireland is explained further. The lower secondlevel science curriculum in Ireland is called Junior Cycle Science Specification (JCSS) and aims to enhance students' knowledge of and about science through a unifying strand, NOS, and the four contextual strands: Physical World, Chemical World, Biological World, and Earth and Space. NOS permeates all strands of the curriculum (DES, 2015). NOS in JCSS consists of different elements, which are understanding about science, investigating in science, communicating in science and science in society.

Concerning entrepreneurship, national strategies for curricular implications including learning outcomes for European schools exist in the literature (European Commission, 2012). Many counties include entrepreneurship in their science curriculum. For example, entrepreneurship is presented as one of the life skills in Turkey (Board of Education and Discipline, 2013) and addressed as transversal competences in Finland (Finnish National Board of Education, 2016). In Ireland, the national skills strategy until 2025 emphasises the importance of entrepreneurship as one of the targeted future national skills at all levels of education. In the Irish national skills strategy, the core (transversal) skills are "creativity, innovation and entrepreneurship, critical and analytical thinking, teamwork, communication and business acumen” (DES, 2016, p. 33). Statement of Learning (SOL) is the learning at the core of the junior cycle, and SOL22 refers to entrepreneurship by stating that "the student takes the initiative, is innovative, and develops entrepreneurial skills" (DES, 2015, p.6). Therefore, entrepreneurship is evident in recent curriculum changes at the lower second level in Ireland, requiring teachers to understand the concept. Upper second level education continues to be dominated by high stakes, external assessment, having a negative backwash effect on teaching, learning and students' experiences of schools (Barnes et al., 2000; Lange and Meaney, 2012).

Numerous studies have identified different factors that need to be considered when reforming a curriculum, and the central role of the teacher in the successful implementation of curriculum reform is acknowledged (Goodson, 2001) and echoed by Fullan (2007, p.129) as "educational change depends on what teachers do and think - it's as simple and complex as that". Acknowledgement of teacher attitudes, values and beliefs are fundamental for curriculum change (Berkovich, 2011; Fullan, 2007), but teachers are more open to changes during their ITE programmes (Decker and Rimm-Kaufman, 2008). Thus, the inclusion of entrepreneurship in the junior cycle has implications for teacher development, including ITE. In the next section, we outline an intervention, including potential activities targeting entrepreneurship in NOS, that we implemented and evaluated with ISTs. 


\section{Methodology}

Qualitative methods help determine the causes of a phenomenon and provide alternative perspectives of the topic investigated, as well as more in-depth information about the research context by focusing on people's perception of the world (Dixon-Woods and Fitzpatrick, 2001). Even if conducted with a small number, in-depth qualitative research conducted over a long period of time can allow us to probe the causes of the problems (Bryman, 2012). Qualitative research aims to determine a detailed understanding of the perceived world by making sense of the data which shows participants' views of the situation (Cohen et al., 2011). Differences in participants' views may be a cursor of their willingness to adapt to the curriculum changes. Therefore, qualitative methods are used to explore the following research questions (RQs):

RQ1: What are the changes in ISTs' understanding of entrepreneurship within the NOS context following an intervention?

RQ2: What are the changes in ISTs' perspectives on the inclusion of entrepreneurship in the science curriculum?

During the participants' science teacher training (i.e. intervention), three applied activities were developed and initially placed with four ISTs. The revised intervention was then implemented with three ISTs in an Irish University for six weeks. The intervention was student-centred, active and engaging using story-based group discussion, concept statement, and crisis management activities that are introduced in Figure 1. These activities were developed based on the literature. The validity and reliability were increased by a thorough review of the literature, making relevant changes based on three experts' opinions, and piloting the instruments with university students who have similar backgrounds.

\section{Story-based group discussion}

This activity was developed based on a story about the discovery of graphene and an activity in Authors (2013) to discuss if science is a social-institutional system.

\section{Concept statement activity}

A concept statement, which is a commonly used technique in business schools, is an overview of a business plan (Etzkowitz, 2008). Participants were asked to come up with a business idea related to science and develop a two-page concept statement in two weeks based on the instructions.

\section{Crisis management activity}

A possible crisis was created from the concept statement, for example, a copyright issue. Having given the example of a crisis situation, participants were asked to come up with a solution.

Figure 1. Three activities used during the intervention

Three second-year undergraduate students, who were studying a Bachelor of Science (Education) Programme in an Irish University, volunteered to participate in this study. Although the research data from a small sample may not be representative statistically, it can 
be an effective way to research and explore unknown aspects and key factors of the topic. All ethical procedures were followed throughout the study, including informed consent and the right to withdraw from the study at any stage. The study also had approval from the relevant University's Research Ethics Committee. The research design is outlined in Figure 2.

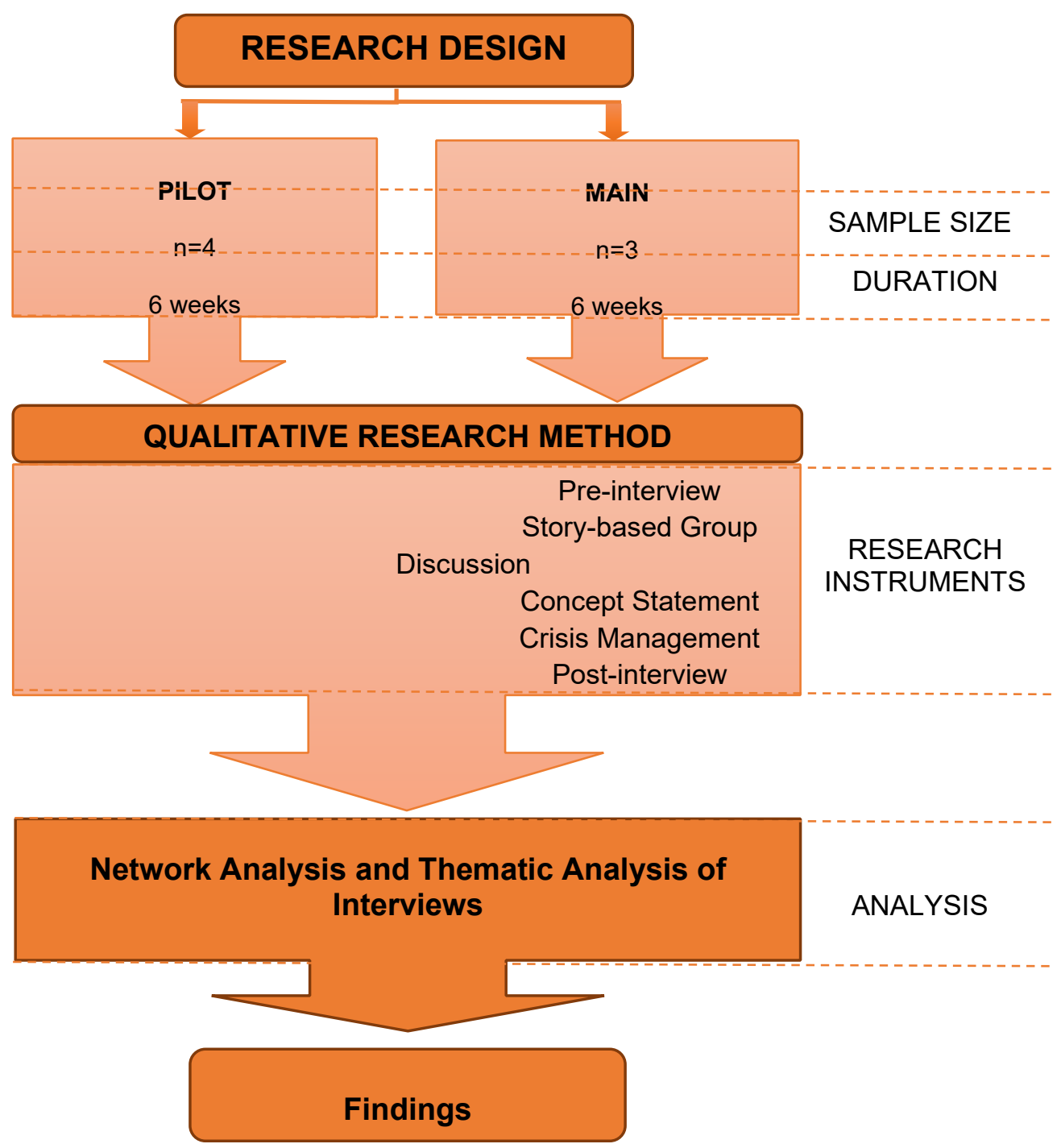

Figure 2. Research design

The three participants, given the synonyms Anne, Mary and Lisa to protect their anonymity, engaged in the intervention activities over six weeks and in semi-structured interviews, preand post-intervention. Pre- and post-interviews explored participants' views and understanding of entrepreneurship, the place of entrepreneurship within NOS and a curriculum. None of the participants came from an entrepreneurial background, while all of them have a family member involved in some type of entrepreneurial activities. Mary had completed a module(s) on entrepreneurship and/or economics at the post-primary level and/or university. 


\section{Data analysis}

The data were analysed using thematic analysis (Braun and Clarke, 2006) and NA (Brandes and Erlebach, 2005; Peters-Burton, 2012) to identify changes in participants' understanding of entrepreneurship in NOS and their perception of the inclusion of entrepreneurship in science curriculum following the intervention.

Network Analysis (NA) is a mathematical analysis using algorithms and theories such as graph theory to model different types of networks (Brandes and Erlebach, 2005; Borgatti et al., 2002; Hanneman and Riddle, 2005). According to Peters-Burton (2012), NOS is a powerful framework for the use of NA and making more connections between NOS aspects illustrates a higher understanding of NOS. "Network analysis can be helpful in forwarding the study of views of the nature of science because of the technique's ability to capture verbatim statements from participants and to display the strength of connections among the statements" (PetersBurton and Baynard, 2013, p.2801). That is, uncovering the way that connections between aspects of the NOS, including entrepreneurship, are understood may result in more effective ways of teaching and learning. To conduct NA, the data were coded based on Table 1 and analysed through UCINet, which is a software package for the analysis of social network data and includes the NetDraw network visualization tool (Borgatti et al., 2002).

Table I. Describing each social aspect of NOS

\begin{tabular}{|c|c|c|}
\hline THEMES & DESCRIPTION \\
\hline Professional Activities & $\begin{array}{r}\text { How scientists engage in professional settings such as attending } \\
\text { conferences and doing publication reviews }\end{array}$ \\
\hline Scientific Ethos & $\begin{array}{c}\text { The norms that scientists employ in their work as well as in } \\
\text { interaction with colleagues }\end{array}$ \\
\hline $\begin{array}{c}\text { Social Certification and } \\
\text { Dissemination }\end{array}$ & $\begin{array}{c}\text { The social mechanism through scientists to review, evaluate and } \\
\text { validate scientific knowledge. E.g. peer-review systems of journals } \\
\text { Social Values of Science }\end{array}$ & $\begin{array}{c}\text { Values such as freedom, respect for the environment, and social } \\
\text { utility }\end{array}$ \\
\hline $\begin{array}{c}\text { Social Organisations } \\
\text { and Interactions }\end{array}$ & $\begin{array}{c}\text { How science is arranged in institutional settings such as universities } \\
\text { and research institutes }\end{array}$ \\
\hline $\begin{array}{c}\text { Political Power } \\
\text { Structures }\end{array}$ & $\begin{array}{c}\text { The dynamics of power that exist between scientists and within } \\
\text { science cultures }\end{array}$ \\
\hline $\begin{array}{c}\text { Economics of Science in } \\
\text { NOS }\end{array}$ & $\begin{array}{c}\text { The underlying economic dimension of science including funding } \\
\text { mechanisms, commercialisation and commodification of science, } \\
\text { and science and scientists in industry }\end{array}$ \\
\hline $\begin{array}{c}\text { Entrepreneurship in } \\
\text { NOS }\end{array}$ & $\begin{array}{c}\text { The underlying enterprising feature of science including scientific } \\
\text { enterprise, entrepreneurial scientists, and creating job opportunities }\end{array}$ \\
\hline
\end{tabular}

Source: Adapted from Kaya (2019), Kaya \& Erduran (2016) and Erduran \& Dagher (2014). 
After completing the NA, participants' pre- and post-interviews were thematically analysed utilising the approach of Braun and Clarke (2006, p.6). Firstly, by familiarizing herself with the data, the researcher was able to understand the depth and breadth of the content. Then, initial themes and subthemes were generated. Emerging sub-themes were re-visited and reorganized to clarify the overall themes and their aspects. The refinements continued until they were not adding anything substantial. Finally, the themes were clearly defined and named.

\section{Main Findings and Discussion}

The findings are presented and discussed under two main headings. Firstly, we argue the impact of the integration of entrepreneurship and NOS to develop a more holistic understanding of ISTs. This is discussed based on the findings from RQ1 on ISTs' understanding of entrepreneurship within the NOS. Secondly, we argue that the impact of national exams on the science curriculum and its potential results should be reconsidered. This is discussed according to the results related to RQ2 on ISTs' perspectives on the inclusion of entrepreneurship in science curriculum. The arguments are presented at the end of each section.

\section{Developing a More Holistic Understanding}

Analysis of the pre- and post-interviews suggested that all three participants developed a broader understanding of entrepreneurship and the integration of entrepreneurship and science as entrepreneurial scientists. Following an intervention, participants could see the bigger picture of science and identify more and complex relationships between entrepreneurship and the social aspects of NOS. All of which infers to the development of a more holistic understanding of entrepreneurship and NOS. Four main themes emerged here.

Entrepreneurship is more than starting a "business":

While participants viewed entrepreneurship purely from a business perspective in the preinterviews, they began to develop a broader and more encompassing understanding of what entrepreneurs do in the post-interviews. This can be observed in Table 2 below.

Table II. Participant' understanding of what entrepreneurs and scientists do in pre- and post-interviews

\begin{tabular}{|l|l|l|}
\hline & Pre-interview & Post-interview \\
\hline Anne & $\begin{array}{l}\text { "Someone [who] } \\
\text { makes their own } \\
\text { business" }\end{array}$ & $\begin{array}{l}\text { "A person or a group of people who come up with a project or } \\
\text { have an idea or something that they want to develop more, and } \\
\text { they can develop a project or get money to develop } \\
\text { something" }\end{array}$ \\
\hline
\end{tabular}




\begin{tabular}{|l|l|l|}
\hline Mary & $\begin{array}{l}\text { "It means business, or } \\
\text { the entrepreneur makes } \\
\text { the product" }\end{array}$ & $\begin{array}{l}\text { "Companies come together with the help of an academic } \\
\text { institution or scientist and they work together as one union to } \\
\text { help produce a product or making a product better to sell it to } \\
\text { the market and therefore making the economy better" }\end{array}$ \\
\hline Lisa & $\begin{array}{l}\text { "Business is what } \\
\text { initiates the market and } \\
\text { identifying what you } \\
\text { can do to fill the gap in } \\
\text { the market" }\end{array}$ & $\begin{array}{l}\text { "Entrepreneurship is spotting a gap in the market or something } \\
\text { that you think you could provide to consumers or coming up } \\
\text { with the idea and then finding the best person to take your idea } \\
\text { and to make a success of it rather that's the entrepreneur } \\
\text { himself or consulting with other investors" }\end{array}$ \\
\hline
\end{tabular}

In Table 2, the data showed that in the pre-interview, participants were confused about the words "entrepreneur" and "entrepreneurship". When they were asked about defining entrepreneurship, all participants referred to business and mostly to a person. Furthermore, participants initially had a narrow understanding of what entrepreneurs and scientists do, as well as having a limited understanding of the relationship between the two. Following engagement in the intervention, participants started to refer to a process rather than a person. Although Anne still referred to "a person or a group of people", she described a process. The participants began to realise, for example, the interrelationships between different stakeholders (e.g. academic and business) and began to develop a broader understanding of what entrepreneurs do.

\section{Entrepreneurs and scientists can "work together":}

In the pre-interview, mostly, it was perceived that a person cannot be both an entrepreneur and a scientist. For example, when Mary was asked if entrepreneurship and science can work together, she stated that "business people and science people would not integrate their work they cannot work together" (pre-interview). Similarly, Anne addressed that "scientists conduct research and projects, and produce products. Then, this can lead to starting a business. If someone has good enough ideas, they can take them (scientists' products) and form their own business." Lisa believed that scientists can be entrepreneurs.

After the intervention (in the post-interview), when asked if a scientist can become an entrepreneur, Mary explained that:

Scientists can have a business background and by bringing that, they might see an opening/gap that might lead them to research in that area. Then they might be able to create a venture or create a product. They would be defined as an entrepreneur then. This is what an entrepreneurial scientist is. 
Entrepreneurship in NOS can help students see "the bigger picture of science":

Participants suggested that the inclusion of entrepreneurship within science could support second level students to make more cross-curricular links between science and other aspects of their learning. Mary, for example, stated that:

Students should learn how science contributes to society. Students should be able to see the cross-curricular links and see the bigger picture of science, not observing it as a subject through one lens. Science should show how science interlinks with other subjects (Mary, post-interview)

It was also suggested that including topics relating to the social aspects of NOS could support second-level students (and teachers) to make connections between science and everyday life. Participants thought that having knowledge of entrepreneurship could enhance students' capacity to identify science in their daily lives. Anne suggested, for example, that:

By including entrepreneurship, students might value what they are learning more and see the use of science around. It may encourage them to keep science subjects and take science courses. It helps students to understand why we are part of science better. (Anne)

Identifying more and more complex relationships between entrepreneurship and the social aspects of NOS:

To identify the ISTs' understanding of the relationship between entrepreneurship and the social aspects of NOS, NA is used as this technique can "capture verbatim statements from participants and display the strength of connections among the statements" (Peters-Burton and Baynard, 2013, p.2801).

By running the UCINet software on the data, NA maps of the participants were created (Appendix 2). These maps illustrate the connections that participants make between entrepreneurship and different social aspects of NOS. For the purposes of this paper, emphasis is placed on degree connectivity and density in NA. On the map, the number of links that participants made between entrepreneurship and different social aspects of NOS were identified and referred to as degree connectivity. Then, the UCINet software calculated the density through the ratio of actual connections to possible connections. The degree connectivity and density of entrepreneurship in NOS are presented in Table 3. The results showed that participants began to make more and complex connections between entrepreneurship and the social aspects of NOS having engaged in the intervention.

Table III. The degree connectivity and density of entrepreneurship (pre- and post-interviews)

\begin{tabular}{|l|l|l|l|}
\hline Type of measurement & Pre-interview & Post-interview \\
\hline
\end{tabular}




\begin{tabular}{|c|c|c|c|}
\hline \multirow{2}{*}{ Anne } & Degree connectivity & 4 & 7 \\
\hline & Density & 2.2857 & 8.7500 \\
\hline \multirow{2}{*}{ Mary } & Degree connectivity & 7 & 7 \\
\hline \multirow{2}{*}{ Lisa } & Density & 3.1250 & 7.7500 \\
\hline & Degree connectivity & 6 & 7 \\
\hline & Density & 2.5714 & 8.3750 \\
\hline
\end{tabular}

Table 3 shows that after the intervention, Anne's level of degree connectivity almost doubled, and the density of entrepreneurship increased over twice as much. The direct relationship of entrepreneurship with professional activities and social values newly emerged in the postinterviews. For example, when explaining how science works in society in the post-interview, Anne stated that "an entrepreneur or a scientist might discover or invent something. Through the professional activities, these are brought to industries, companies, academic institutions...". That is, Anne could identify more and complex relationships between entrepreneurship and the other social aspects of NOS.

Lisa's level of degree connectivity and density also increased after engaging in the intervention. In the post-interview, the density of entrepreneurship increased over three times. That is, Lisa could identify more and complex relationships between entrepreneurship and the other social aspects of NOS. Several relationships that Lisa could make can be seen in the excerpt of the post-interview:

If an entrepreneur discovers a scientific-based product or service or anything, they probably will be consulting with a group of scientists to further explore it in more detail. They are going to gain extra knowledge by researching it. Then, when they have their idea or their knowledge explored, they are probably ready to start making some kind of prototype or an example of whatever they are doing. They may need resources for this. They could go to the government for funding.

For Mary, while the density of entrepreneurship increased over twice as much, the degree connectivity stayed almost the same. This may indicate that while Mary's understanding of the importance of entrepreneurship in the social aspects of NOS stayed almost the same, her understanding of the connection of entrepreneurship to the social aspects of NOS increased. Mary could identify more, and complex, relationships between entrepreneurship and the other social aspects of NOS. For example, Mary was making a connection between scientific ethos, 
social values, organisations and interactions, political power structures, economics of science and entrepreneurship, when she said:

I suppose it is not really a great idea to be setting up a business or getting into an industry or conducting an experiment on something in a country that is against their religion or race, like cloning. Some parts of the world might be open to it, but some governments might be completely against it.

It is worth mentioning that Mary was one of the participants who completed a module on entrepreneurship prior to engaging in the intervention. Therefore, this might have affected the result.

Participants initially appeared to have a limited and, what we have labelled, "fragmented" understanding of the relationship between the social aspects of NOS, as well as between scientists and entrepreneurs. By this, we mean that they were unable to see how these concepts interconnect with each other and tended to perceive concepts as separate entities (Beane, 1995). Throughout their entire educational experience, these ISTs have experienced knowledge as something that is neatly divided, packaged as discrete forms of knowledge with limited connections across and between subjects (Gleeson, 2010). Beane (1995) suggests that presenting and structuring knowledge in such a way can have a negative impact on students' capacity to make connections between concepts. He argues that:

There is no unity, no real sense to it all. It is as if in real life, when faced with problems or puzzling situations, we stopped to ask which part is science, which part mathematics, which part art, and so on (p.420).

Such a fragmented understanding is not surprising when one considers that fragmentation is a common feature of the Irish education system. This fragmentation is evident at a macro level in terms of how the curriculum is developed in Ireland (Gleeson, 2010) and how teacher education is structured (Teaching Council of Ireland, 2011). Of particular relevance here is the continued fragmentation of knowledge within education systems - not just within an Irish context (ibid).

However, findings in the current study show that change is possible in this regard with ISTs, for example, starting to combine the role of a scientist and an entrepreneur as in entrepreneurial scientists. Forming a more rounded and holistic understanding can help ISTs (and their students) understand science in its entirety (Erduran and Dagher, 2014; Irzik and Nola, 2014). Supporting such an understanding enhances cross-curriculum links (Ezeudu et al., 2013; Palmer and Johansson, 2018; Wang and Kleppe, 2001) by supporting ISTs to relate science to the environment and can also broaden IST's (and their students) perspectives, helping them to think outside of the box. This might support ISTs to present their subject area in a more holistic manner, supporting students to do likewise. This may result in teachers and students who view knowledge more broadly. Surely this is what we want from our science teachers and science education! 


\section{The Impact of National Exams on the Science Curriculum}

Both pre- and post-interviews explored IST's views regarding the inclusion of entrepreneurship in the science curriculum. Analysis of the interviews suggested that, following engagement in the intervention, all three participants saw the benefits and rationale for including entrepreneurship in the science curriculum, but certain concerns remained. These concerns point to the pressure exerted by national exams on the students, which has a negative impact on the student perspectives. Two main findings are now outlined and discussed.

\section{Making science more engaging: "Entrepreneurship would make science more interesting":}

All participants, especially Lisa and Anne, saw the benefits of including entrepreneurship within the science curriculum. This was evident in both the pre- and post-interviews. In the pre-interview, Anne and Lisa suggested that such inclusion would "make science more interesting" (Anne, pre-interview), would "motivate people to like science more" (Anne, preinterview) and would get them to be "much more focused and enjoy science" (Lisa, preinterview). Such views continued throughout the post-interviews as reflected in the excerpt below:

When entrepreneurship is included in science classes, students will probably find it more interesting. They might think 'Oh! I can discover something.' They'd probably be more engaged in the class. (Anne, post-interview)

Participants also felt that such inclusion would support students to develop a better understanding of why they are learning something, the process that scientists engage in reallife contexts, and may support students to gain an understanding of the bigger picture. The following excerpt, while long, reflects participants views well in this regard:

Entrepreneurship is something I think would be good in the classroom. I think it makes students much more appreciative of where things came from, can get them much more focused on and enjoy science. If they had to think for themselves, how to turn an object, such as a phone, into something else, something innovative so they will think about science in a different way rather than what they see in the book in front of them. They will think of science in a bigger context, like in society, rather than what is on the curriculum (Lisa, pre-interview)

Mary, who did not tend to agree with the inclusion of entrepreneurship in the science curriculum in the pre-interview (as outlined above), suggested in her post-interview that such inclusion could support students to identify concrete examples for abstract ideas. Mary felt that "it would be good to include it in science classes because it's nice to see real-life examples. Science can sometimes be very abstract and it's good to take things that are happening in society and you know put into an everyday perspective for students to understand the concept behind it.....what science is all about..." (Mary, post-interview).

The impact of national exams: "That isn't gonna come up in your exam":

Mixed views emerged in the pre-interview in terms of the inclusion of entrepreneurship in the 
science curriculum and while participants were initially supportive of such inclusion, this was frequently followed by "but.....". In the post-interviews, although all participants were supportive of this inclusion, they raised concerns about it due to the busy curriculum schedule.

All three participants initially expressed some reservations regarding the potential to include entrepreneurship within the science curriculum due to pressure on teachers to cover content for the exam. All three mentioned this in the pre-interview while Mary continued this discussion in the post-interviews. As reflected in the title, Lisa initially suggested that while important, entrepreneurship within science wasn't as important as other topics, as it "wasn't gonna come up in your exam" (Lisa, pre-interview). Similarly, Mary argued that "at the end of the day, students have an exam to do" (pre-interview). Participants felt that teachers had too much material to cover already and, if entrepreneurship were to be included, an already existing aspect of the curriculum would need to be removed.

Within the pre-interviews, participants tended to perceive entrepreneurship as something additional (and different to science) that would add extra pressure on teachers, reducing the time they had to explore 'science' with their students. Mary's comment that "if we have to do that for every single concept, we cannot do science" (pre-interview) is telling in this regard. Analysis of the post-interviews indicates that Mary began to see the potential to integrate entrepreneurship as examples within NOS/science but that concerns regarding the exam remained:

Use it to explain abstract and certain aspects of science. I would just probably give the examples, but I wouldn't be spending two or three weeks working on it because, at the end of the day, they're not being tested on this (Mary, post-interview)

These findings need to be situated in context. Upper second level education in Ireland continues to be dominated by high stakes, external assessment, having a negative backwash effect on teaching, learning and students' experiences of schools (Barnes et al., 2000; Lange and Meaney, 2012). Until recently, the assessments at junior cycle have been viewed as a dry run for the upper second level exams. This might then mean that supporting students and teachers to move away from the prescribed curriculum might be a challenge (Hynes et al., 2010). Staying with a prescribed curriculum can result in having students who are unable to think out of the box, who struggle to think innovatively and only think in terms of exams. The integration of entrepreneurship in NOS may help make science more interesting and engaging, support students (and teachers) to see the bigger picture of science and create something. In this study, the inclusion of entrepreneurship into science education was limited to the activities applied. Participants were not provided with any additional lectures to support their learning. The outcome of this study is a result of making participants question and think about a topic over a six-week period, so imagine what differences may emerge across four years of ITE and beyond. 


\section{Conclusion}

This study investigated the changes in ISTs' (a) understanding of entrepreneurship within the NOS context and (b) perspectives on the inclusion of entrepreneurship in the science curriculum following an intervention. The results showed that following an intervention, ISTs developed a more holistic understanding of entrepreneurship in NOS. This is evident in the thematic analysis results as ISTs started to perceive entrepreneurship from a broader perspective, the integration of science and entrepreneurship as entrepreneurial scientists, and cross-curricular links between them. Additionally, NA supports this argument by indicating that ISTs identified more and complex relationships between entrepreneurship and the social aspects of NOS following an intervention. Thematic analysis results also suggest that although ISTs could see the benefits and rationale for including entrepreneurship in the science curriculum, certain concerns remained. The results indicate that the inclusion of entrepreneurship in NOS has potential but the impact of national exams on the curriculum should be considered during its integration and implementation. Further research should be conducted on the curriculum integration of entrepreneurship and its impact on ITE.

Developing science teachers, who have a holistic understanding of science and NOS and can develop the same understanding amongst their students, holds certain implications for the ITE these science teachers experience. ITE should consider how to create synergy between topics to ensure a holistic understanding is developed and support developing educational content aiming to increase ISTs' competence and experience concerning entrepreneurship in science (Deveci, 2016). This may sometimes be provided by (a) simply raising some questions related to the topic, (b) conducting content-related, pedagogically appropriate practical activities with ISTs, (c) providing the stories of entrepreneurial scientists and/or (d) bringing experts working in a company to meet with ISTs. The activity types utilised in this study can be used in this regard.

Overall, embedding entrepreneurship into NOS is uncharted territory. This study is of importance because providing the data on ISTs' perspectives of entrepreneurship in NOS contributes to the literature by building on what is known and how this can be developed further. Investigating the implications of entrepreneurship in NOS further might contribute to help students understand complex ideas, develop $21^{\text {st }}$ century skills, make students realise the applications of science in everyday life and comprehend science as a whole, and thereby increase the engagement and interest in science during their teaching practices. This can support us to have "a nation of people armed with relevant knowledge, entrepreneurial agility and analytical skills" (DES, 2016, p.69). 


\section{Reference List}

Achor, E. E. and Wilfred-Bonse, U. K. (2013), "The need to integrate entrepreneurship education into science education teachers' curriculum in Nigeria", Journal of Science and Vocational Education, Vol. 7, pp. 111-123.

Akbayrak, M., \& Kaya, E. (2020) Fifth-grade students' understanding of social-institutional aspects of science, International Journal of Science Education, 42:11, 18341861, DOI: $10.1080 / 09500693.2020 .1790054$

Allchin, D. (2011), "Evaluating knowledge of the nature of (whole) science", Science Education, Vol. 95 No. 3, pp. 518-542. https://doi.org/10.1002/sce.20432.

Amos, A. A. and Onifade, C. A. (2013), "The perception of students on the need for entrepreneurship education in teacher education programme", Global Journal of Human Social Science, Vol. 13 No. 3, pp. 75-80.

Anderson, M., Hinz, B. and Matus, H. (2017), The Paradigm Shifters: Entrepreneurial learning in schools, Mitchell Institute, Melbourne.

Bakhshi, H., Downing, J. M., Osborne, M. A. and Schneider, P. (2017), The Future of Skills: Employment in 2030, Pearson and Nesta, London.

Barnes, M., Clarke, D., and Stephens, M. (2000), "Assessment: the engine of systemic curricular reform?", Journal of Curriculum Studies, Vol. 32 No. 5, pp. 623-650. https://doi.org/10.1080/00220270050116923.

Beane, J. A. (1995), "Curriculum integration and the disciplines of knowledge", The Phi Delta Kappan, Vol. 76 No: 8, pp. 616-622.

Berkovich, I. (2011), “No, we won't! Teachers' resistance to educational reform', Journal of Educational Administration, Vol. 49 No. 5, pp. 563-578. https://doi.org/10.1108/09578231111159548.

Board of Education and Discipline (2013), Turkish Science Curriculum, Board of Education and Discipline, Ankara.

Borgatti, S.P., Everett, M.G. and Freeman, L.C. (2002), UCINET for Windows: Software for social network analysis, Analytic Technologies, Harvard, MA.

Brandes, U. and Erlebach, T. (2005), Network Analysis: Methodological foundations, Springer, Berlin, Heidelberg.

Braun, V. and Clarke, V. (2006), "Using thematic analysis in psychology", Qualitative Research in Psychology, Vol. 3 No. 2, pp. 77-101. https://doi.org/10.1191/1478088706qp063oa.

Bruyat, C. and Julien, P. A. (2001), "Defining the field of research in entrepreneurship", Journal of Business Venturing, Vol. 16 No. 2, pp. 165-180. https://doi.org/10.1016/S0883-9026(99)00043-9. 
Bryman, A. (2012), Social Research Methods, Oxford University Press, New York, NY.

Buang, N. A., Halim, L. and Meerah, T. S. M. (2009), "Understanding the thinking of scientists entrepreneurs: implications for science education in Malaysia", Journal of Turkish Science Education, Vol. 6 No. 2, pp. 3-11.

Busch, L. M., and Lacy, W. B. (2019), The Agricultural Scientific Enterprise: A system in transition, Routledge, New York, NY.

Clough, M.P. (2011), "Teaching and assessing the nature of science", The Science Teacher, Vol. 78 No. 6, pp. 56-60.

Cohen, L., Manion, L. and Morrison, K. (2011), Research Methods in Education, Routledge, New York, NY.

Cornbleth, C. (1990), Curriculum in Context, Falmer, London.

Decker, L. E., and Rimm-Kaufman, S. E. (2008), "Personality characteristics and teacher beliefs among pre-service teachers", Teacher Education Quarterly, Vol. 35 No. 2, pp. $45-64$.

Department of Business, Enterprise and Innovation (2018), Enterprise 2025 Renewed: Building resilience in the face of global challenges, Dublin, Department of Business, Enterprise and Innovation. Retrieved from https://enterprise.gov.ie/en/Publications/Publication-files/Enterprise-2025Renewed.pdf.

DES (Department of Education and Skills) (2015), Junior Cycle Science Curriculum Specification, Dublin, Communications Unit Department of Education and Science, pp. 1-26.

DES (Department of Education and Skills) (2016), Ireland's National Skills Strategy 2025, Dublin, Communications Unit Department of Education and Science, pp. 1-123.

Deveci, I. (2016), "Perceptions and competence of Turkish pre-service science teachers with regard to entrepreneurship", Australian Journal of Teacher Education, Vol. 41 No. 5, pp. 153-170.

Deveci, I., and Seikkula-Leino, J. (2018), "A review of entrepreneurship education in teacher education", Malaysian Journal of Learning and Instruction, Vol. 15 No. 1, pp. 105148.

Dixon-Woods, M. and Fitzpatrick, R. (2001), "Qualitative research in systematic reviews: has established a place for itself”, BMJ: British Medical Journal, Vol. 323 No. 7316, pp. 765-766. https://doi.org/10.1136/bmj.323.7316.765.

Ehrlin, A., Insulander, E., and Sandberg, A. (2016), "The transformation of creativity in entrepreneurial learning in teacher education: a critical reflection”, Australian Journal of Teacher Education, Vol. 41 No.6, pp. 35-51. 
Erduran, S., and Dagher, Z. R. (2014), Reconceptualizing the Nature of Science for Science Education: Scientific knowledge, practices and other family categories, Springer, Dordrecht.

Erduran, S., \& Mugaloglu, E. (2013). Interactions of Economics of Science and Science Education: Investigating the Implications for Science Teaching and Learning. Science \& Education, 22(10), 2405-2425.

Etzkowitz, H. (2008), The Triple Helix: University-industry-government innovation in action, Routledge, New York, NY.

European Commission (2012), Entrepreneurship Education at School in Europe: National strategies, curricula and learning outcomes, European Commission, Brussels.

Ezeudu, F. O., Ofoegbu, T. O. and Anyaegbunnam, N. J. (2013), "Restructuring STM (Science, Technology, and Mathematics) education for entrepreneurship", Online Submission, Vol. 3 No. 1, pp. 27-32.

Finnish National Board of Education (2016), New National Core Curriculum for Basic Education: Focus on school culture and integrative approach, Finnish National Agency for Education, Helsinki.

Fullan, M. (2007), The New Meaning of Educational Change, Routledge, London.

Gleeson, J. (2010), Curriculum in Context: Partnership, power and praxis in Ireland, Peter Lang, Germany.

Goodson, I. F. (2001), "Social histories of educational change", Journal of Educational Change, Vol. 2 No. 1, pp. 45-63. https://doi.org/10.1023/A:1011508128957.

Gustafsson-Pesonen, A. and Remes, L. (2012), "Evaluation of entrepreneurial development coaching: changing the teachers' thinking and action on entrepreneurship", Annals of Innovation and Entrepreneurship, Vol. 3 No. 1, pp. 1-12. https://doi.org/10.3402/aie.v3i0.17292.

Hanneman, R. and Riddle, M. (2005), Introduction to Social Network Analysis, University of California, Riverside CA.

Hisrich, R. D. and Peters, M. P. (2002), Entrepreneurship, McGraw-Hill, New Delhi.

Hynes, B., Costin, Y. and Birdthistle, N. (2010), "Practice-based learning in entrepreneurship education: a means of connecting knowledge producers and users", Higher Education, Skills and Work-based Learning, Vol. 1 No. 1, pp. 16-28. https://doi.org/10.1108/20423891111085366.

Irzik, G. and Nola, R. (2011), "A family resemblance approach to the nature of science for science education", Science and Education, Vol. 20 No. 7, pp. 591-607. https://doi.org/10.1007/s11191-010-9293-4.

Irzik, G. and Nola, R. (2014), "New directions for nature of science research", Matthews M. (Ed.), International Handbook of Research in History, Philosophy and Science 
Teaching, Springer, Dordrecht, pp. 999-1021. https://doi.org/10.1007/978-94-0077654-8_30.

Jiang, H., Xiong, W. and Cao, Y. (2017), "Research on the mechanism of entrepreneurial education quality, entrepreneurial self-efficacy and entrepreneurial intention in social sciences, engineering and science education", EURASIA Journal of Mathematics, Science and Technology Education, Vol. 13 No. 7, pp. 3709-3721. https://doi.org/10.12973/eurasia.2017.00754a.

Kampourakis, K. (2016), "The "general aspects" conceptualization as a pragmatic and effective means to introducing students to nature of science", Journal of Research in Science Teaching, Vol. 53 No. 5, pp. 667-682. https://doi.org/10.1002/tea.21305.

Kaya, S. (2019), Enhancing Pre-service Science Teachers' Understanding of How Science Works in Society: The role of economics and entrepreneurship in nature and science. Unpublished PhD Thesis, The Republic of Ireland, University of Limerick, Limerick.

Kaya, E., Erduran, S., Aksoz, B. \& Akgun, S. (2019). Reconceptualised Family Resemblance Approach to Nature of Science in pre-service science teacher education. International Journal of Science Education, 41(1), pp.21-47, DOI: 10.1080/09500693.2018.1529447.

Kaya, E. and Erduran, S. (2016), "From FRA to RFN, or how the family resemblance approach can be transformed for science curriculum analysis on nature of science", Science and Education, Vol. 25 No. 9-10, pp. 1115-1133. https://doi.org/10.1007/s11191-0169861-3.

Kaya, S., Erduran, S., Birdthistle, N. and McCormack, O. (2018), "Looking at the social aspects of nature of science in science education through a new lens: the role of economics and entrepreneurship", Science and Education, Vol. 27 No. 5-6, pp. 457478. https://doi.org/10.1007/s11191-018-9990-y.

Lange, T., and Meaney, T. (2012), "The tail wagging the dog?: the effect of national testing on teachers' agency", Evaluation and Comparison of Mathematical Achievement: Dimensions and Perspectives: Proceedings of MADIF, Svensk Förening för MatematikDidaktisk Forskning - SMDF, pp. 131-140, Available at https://www.divaportal.org/smash/get/diva2:1408188/FULLTEXT01.pdf.

Leask, B. (2008), "Internationalisation, globalisation and curriculum innovation", in Hellstén M., and Reid A. (Eds.), Researching International Pedagogies. Springer, Dordrecht, pp. 9-26. https://doi.org/10.1007/978-1-4020-8858-2_2.

Lepisto, J., and Ronkko, M. L. (2013), "Teacher students as future entrepreneurship educators and learning facilitators", Education + Training, Vol. 55 No. 7, pp. 641-653. https://doi.org/10.1108/ET-05-2012-0055. 
Li L. and Ruppar A. (2021), "Conceptualizing teacher agency for inclusive education: a systematic and international review", Teacher Education and Special Education, Vol. 44 No. 1, pp. 42-59. https://doi.org/10.1177/0888406420926976.

Matthews, M. R. (2012), "Changing the focus: from nature of science (NOS) to features of science (FOS)", in Khine M. S. (Ed.), Advances in Nature of Science Research, Springer, Dordrecht, pp. 3-26.

Mccallum, E., Weicht, R., Mcmullan, L. and Price, A. (2018), EntreComp into Action - Get Inspired, Make it Happen: A user guide to the European entrepreneurship competence framework, Bacigalupo, M. and O'keeffe, W. (Ed.s), Publications Office of the European Union, Luxembourg. https://doi.org/10.2760/574864.

McComas, W. F., Clough, M. P., and Almazroa, H. (1998), "The role and character of the nature of science in science education", in W. F. McComas (Ed.), The nature of Science in Science Education, Springer, Dordrecht, pp. 3-39.

McLoughlin E., Butler., D., Kaya, S. and Costello, E. (2020), STEM Education in Schools: What can we learn from the research?, Dublin City University, The Republic of Ireland. http://dx.doi.org/10.5281/zenodo.3673728.

Palmer, H. and Johansson, M. (2018), "Combining entrepreneurship and mathematics in primary school-what happens?”, Education Inquiry, Vol. 9 No. 4, pp. 331-346. https://doi.org/10.1080/20004508.2018.1461497.

Park, W., Yang, S. and Song, J. (2020), “Eliciting students' understanding of nature of science with text-based tasks: insights from new Korean high school textbooks", International Journal of Science Education, Vol. 42 No. 3, pp. 426-450. https://doi.org/10.1080/09500693.2020.1714094.

Peters-Burton, E. (2012), "Modelling relationships among aspects of NOS: presenting cooccurrences with epistemic network analysis", paper presented at the National Association for Research in Science Teaching (NARST): 2012 Annual International Conference, 25-28 March, Indiana, United States.

Peters-Burton, E. and Baynard, L. R. (2013), "Network analysis of beliefs about the scientific enterprise: a comparison of scientists, middle school science teachers and eighthgrade science students", International Journal of Science Education, Vol. 35 No. 16, pp. 2801-2837. https://doi.org/10.1080/09500693.2012.662609.

Sanders, M. (2007), "Scientific paradigms, entrepreneurial opportunities and cycles in economic growth", Small Business Economics, Vol. 28 No. 4, pp. 339-354. https://doi.org/10.1007/s11187-006-9038-6.

Seikkula-Leino, J., Ruskovaara, E., Ikavalko, M., Mattila, J. and Rytkola, T. (2010), "Promoting entrepreneurship education: the role of the teacher?", Education + Training, Vol. 52 No. 2, pp. 117-127. https://doi.org/10.1108/00400911011027716. 
Teaching Council of Ireland (2011), Policy on the Continuum of Teacher Education, Teaching Council, Maynooth.

Timmons, J. A. (1989), The Entrepreneurial Mind, Brick House Publishing, Andover.

Wilson, K. E., Volkmann, C., Mariotti, S., Rabuzzi, D. Vyakarnam, S. and Sepulveda, A. (2009), Educating the Next Wave of Entrepreneurs: Unlocking entrepreneurial capabilities to meet the global challenges of the $21^{\text {st }}$ century, World Economic Forum, Switzerland.

Wang, E.L. and Kleppe, J.A. (2001), "Teaching invention, innovation, and entrepreneurship in engineering", Journal of Engineering Education, Vol. 90 No. 4, pp. 565-570. https://doi.org/10.1002/j.2168-9830.2001.tb00640.x. 


\section{Appendices}

Appendix 1: Studies published on entrepreneurship in ISTE between 2015-2021

\begin{tabular}{|c|c|c|}
\hline $\begin{array}{l}\text { Author(s) } \\
\text { and Year }\end{array}$ & Title & Summary \\
\hline $\begin{array}{l}\text { Deveci and } \\
\text { Cepni (2015) }\end{array}$ & $\begin{array}{l}\text { Examining Science Teacher Candidates' } \\
\text { Entrepreneurial Characteristics According to } \\
\text { Some Variables }\end{array}$ & $\begin{array}{l}\text { The study results suggested considering variables, such as gender, work } \\
\text { experience, receiving awards, and grade level when implementing } \\
\text { entrepreneurship into ISTE. }\end{array}$ \\
\hline $\begin{array}{l}\text { Deveci } \\
(2016 a)\end{array}$ & $\begin{array}{l}\text { Perceptions and competence of Turkish } \\
\text { pre-service science teachers with regard to } \\
\text { entrepreneurship }\end{array}$ & $\begin{array}{l}\text { The results showed that participants had an inadequate level of } \\
\text { entrepreneurship competences as well as having a limited understanding of } \\
\text { entrepreneurship. The authors argued the necessity of developing effective } \\
\text { content and practices to develop IST' competence and understanding of } \\
\text { entrepreneurship through ISTE. }\end{array}$ \\
\hline $\begin{array}{l}\text { Deveci } \\
(2016 b)\end{array}$ & $\begin{array}{l}\text { Science-based entrepreneur project development } \\
\text { process for pre-service science teachers: } \\
\text { Difficulties faced }\end{array}$ & $\begin{array}{l}\text { The study showed the need for developing ISTs'entrepreneurship competence } \\
\text { which may require developing effective entrepreneurship content and practices } \\
\text { for ISTE. }\end{array}$ \\
\hline $\begin{array}{l}\text { Igboegwu } \\
(2016)\end{array}$ & $\begin{array}{l}\text { Developing Entrepreneurial Skills in Female } \\
\text { Pre-Service Chemistry Educators through } \\
\text { Science Education: A Path to Women } \\
\text { Empowerment in Nigeria }\end{array}$ & $\begin{array}{l}\text { The findings indicated that the participants were not exposed to any } \\
\text { entrepreneurial skills. The study recommended developing strategies, facilities } \\
\text { and materials that develop entrepreneurial skills. }\end{array}$ \\
\hline $\begin{array}{l}\text { Deveci and } \\
\text { Cepni (2017) }\end{array}$ & $\begin{array}{l}\text { The effect of entrepreneurship education } \\
\text { modules integrated with science education on } \\
\text { the entrepreneurial characteristics of pre-service } \\
\text { science teachers }\end{array}$ & $\begin{array}{l}\text { The authors suggested improving the entrepreneurial characteristics of ISTs } \\
\text { through modules and seminars. }\end{array}$ \\
\hline $\begin{array}{l}\text { Olotu and } \\
\text { Ugwuanyi } \\
(2017)\end{array}$ & $\begin{array}{l}\text { Science Education and Entrepreneurship for } \\
\text { National Growth and Development }\end{array}$ & $\begin{array}{l}\text { The authors argue the importance of integrating entrepreneurship into ISTEs to } \\
\text { decrease unemployment through self-employment and job creation and } \\
\text { promote the development of a nation. The authors suggest (1) providing ISTs } \\
\text { with real-world contexts, (2) integrating innovative teaching strategies into } \\
\text { ISTE that improves risk-taking skills and knowledge for investment and } \\
\text { business management, and (3) governments to build on the infrastructure with, } \\
\text { for example, employing more teachers where necessary supporting } \\
\text { entrepreneurs. }\end{array}$ \\
\hline $\begin{array}{l}\text { Authors } \\
(2017)\end{array}$ & & $\begin{array}{l}\text { The results showed that ISTs knowledge on entrepreneurship improved, and } \\
\text { their perspectives on the role of entrepreneurship in science changed positively } \\
\text { following an intervention. The authors believe that increasing the perspectives } \\
\text { of ISTs on entrepreneurship is likely to help them in addressing science in its } \\
\text { wider socio-economic context. }\end{array}$ \\
\hline $\begin{array}{l}\text { Authors } \\
\text { (2018) }\end{array}$ & & $\begin{array}{l}\text { The authors proposed the inclusion of entrepreneurship as part of } \\
\text { contemporary social aspects of NOS, and by drawing on the entrepreneurship } \\
\text { literature, proposed the SAMI (state- academia- market- industry) cycle to } \\
\text { explain how science works in society. The authors suggested practical lesson } \\
\text { activities for implementing entrepreneurship into NOS. }\end{array}$ \\
\hline Ergun (2019) & $\begin{array}{l}\text { Examining the STEM Awareness and } \\
\text { Entrepreneurship Levels of Pre-Service Science } \\
\text { Teachers }\end{array}$ & $\begin{array}{l}\text { The results demonstrated that while gender did not have a significant impact } \\
\text { on entrepreneurship levels, second-year ISTs' entrepreneurship characteristics } \\
\text { were significantly higher than the other grade levels. }\end{array}$ \\
\hline $\begin{array}{l}\text { Ugwuanyi, } \\
\text { Okeke \& Ene } \\
\text { (2019) }\end{array}$ & $\begin{array}{l}\text { Factorial validation of entrepreneurship mindset } \\
\text { scale of science education undergraduate } \\
\text { students }\end{array}$ & $\begin{array}{l}\text { The authors recommended both state and federal governments to support } \\
\text { graduates on their entrepreneurial skills and organise free seminars, } \\
\text { conferences and workshops on developing an entrepreneurial mindset. }\end{array}$ \\
\hline $\begin{array}{l}\text { Agunbiade- } \\
\text { Olu (2020) }\end{array}$ & $\begin{array}{l}\text { Influence of Science Education on the Choice of } \\
\text { Entrepreneurial Skills Among Undergraduates } \\
\text { of Universities in Ekiti State, Nigeria }\end{array}$ & The authors recommended incorporating entrepreneurship into ISTE. \\
\hline
\end{tabular}


Anne's network analysis maps from pre-interview (top) and post-interview (bottom)
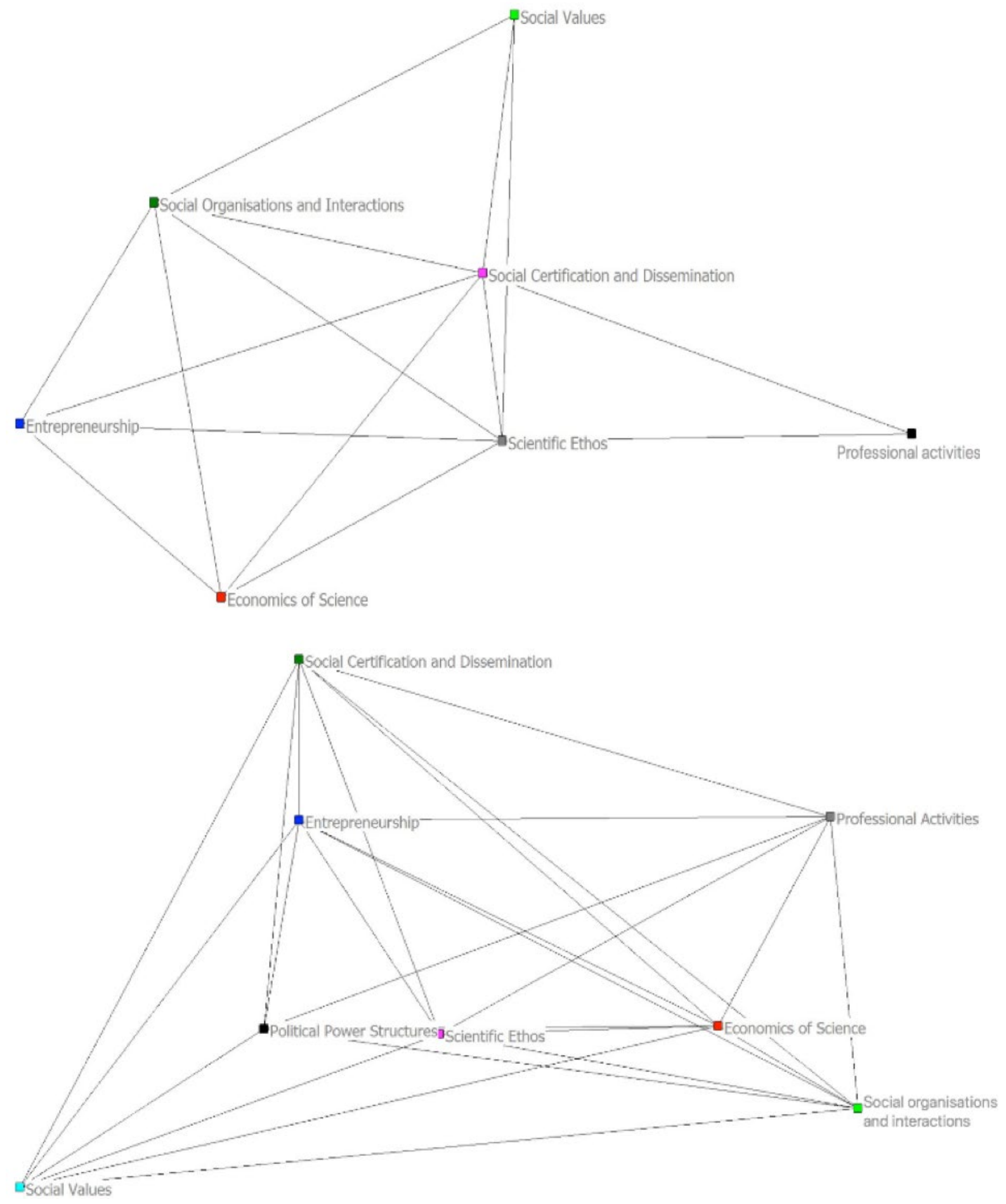

Mary's network analysis maps from pre-interview (top) and post-interview (bottom) 

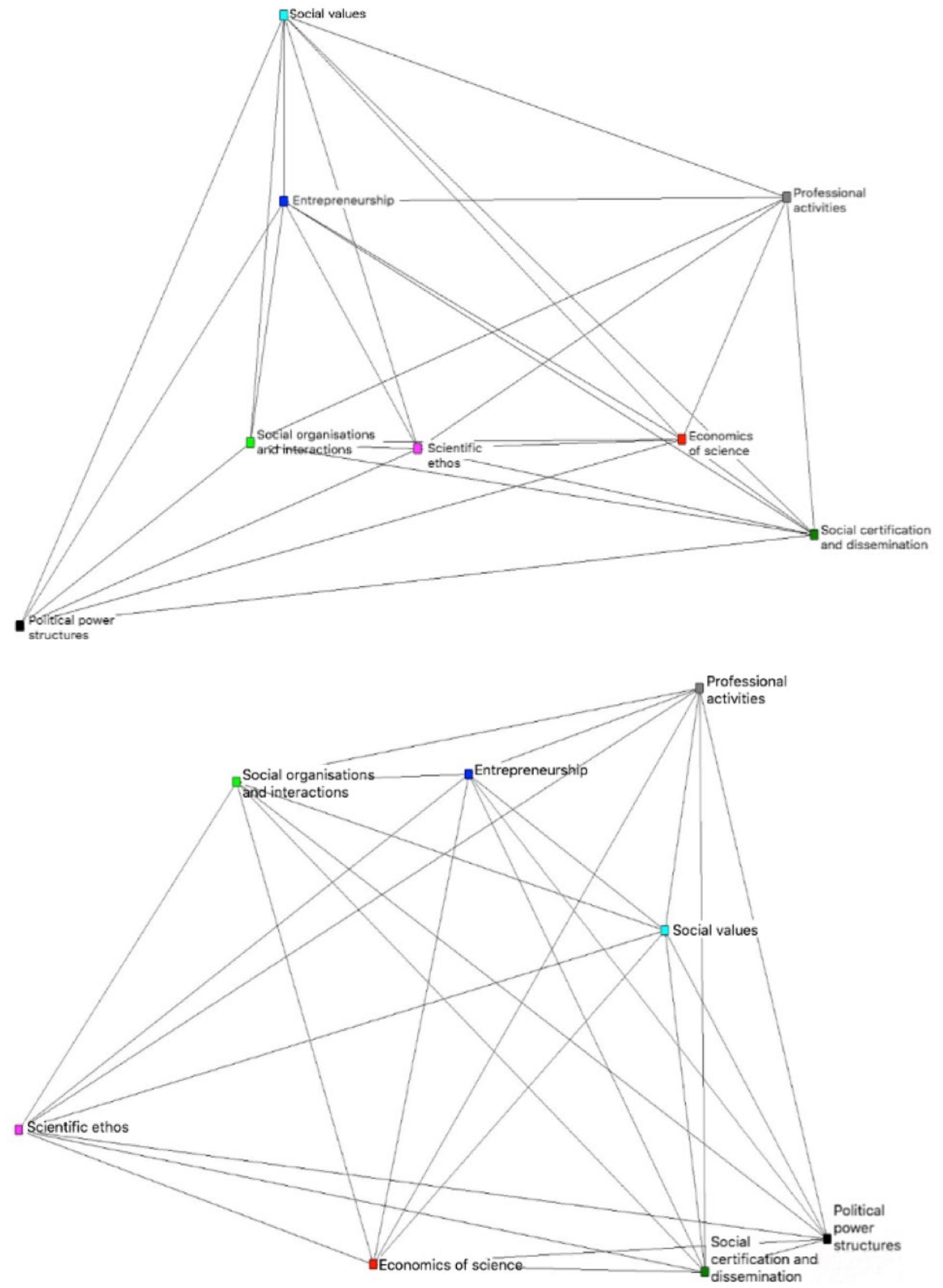

Lisa's network analysis maps from pre-interview (top) and post-interview (bottom) 

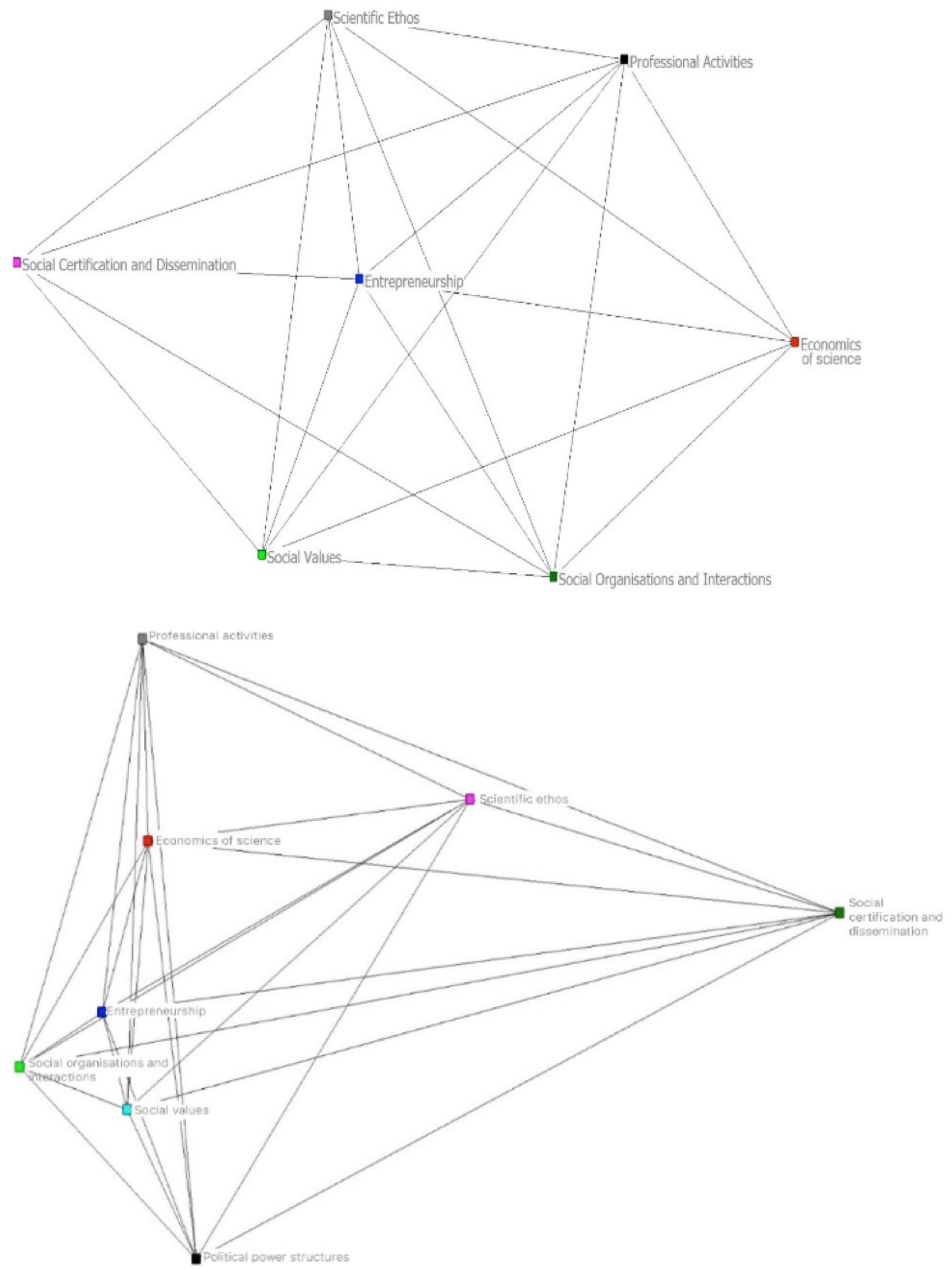